the demand for it has proved so great that this new edition has been issued by the University of Oklahoma Press. Apart from a short preface reviewing progress since 1950 , it is a facsimile reproduction of the first edition, with the welcome addition of a substantial binding. Experience has shown that a word of explanation about the title of this massive work will not come amiss; far from being a mere introduction to Maya hieroglyphics, it is a very profound study of this difficult subject, but it was also designed to introduce a dictionary of non-calendrical glyphs, a work which the author has only just finished. Eric Thompson has studied the Maya for the past thirty years or so, and has long been known as one of the foremost authorities on their hieroglyphic writing. This book has added greatly to his reputation.

It contains a wealth of detailed information about the various types of Maya inscription, those cut in wood and stone, and those painted in the manuscripts and to a lesser extent on wall or pot. Each of the great synchronized cycles which make up the calendar is considered, and new light is thrown on divinatory inscriptions. All this reveals the staggering complexity of the subject ; but the treatment is lightened by the author's constant insistence on human and spiritual factors and by the happiness of his style. He says in effect that mathematics and astronomy have an essential part in this study, but that an understanding of Maya religion and mythology is as important, and he goes so far as to say that "Mysticism, religion and poetry completely dominate their hieroglyphic writing." It is emphasized that the whole of Maya religion revolved around the majestic conception of the eternal march of time, in which the periods into which the calendar is divided are borne along by the gods, who pause only to change their burdens over like relay runners at the appropriate period endings. This is graphically shown on the most elaborate form of inscription, the full-figure glyphs exemplified by Stela $D$ at Copan, of which a free modern version forms the frontispiece.

The brevity of this notice is not a measure of the importance of the book, which is unsurpassed in its own field, but of the small number of those who concern themselves with the study of the Maya in Great Britain. It is pleasant to record that the author himself has returned to swell their number after living for many years in the New World, and it is to be hoped that his new Glyphic Dictionary will soon be published.

G. H. S. Bushneli

\section{WORLD DISTRIBUTION OF ABO BLOOD GROUPS}

The ABO Blood Groups

Comprehensive Tables and Maps of World Distribution. By Dr. A. E. Mourant, Ada C. Kopeć and Kazimiera Domaniewska-Sobczak. (Occasional Publication No. 13 of the Royal Anthropological Institute.) Pp. viii +276. (Oxford: Blackwell Scientific Publications; Springfield, Ill.: Charles C. Thomas, Publisher, 1958.) 42s. net.

R. MOURANT and his colleagues have brought together all the results published up to the end of 1957 on the frequency of the $A B O$ blood groups in the human population; the figures are given for the majority of areas in the world. The result is a most comprehensive book on the distribution of these groups incorporating 1,056 references and 6 maps.
After a short introduction, the information is given in the form of tables. These show place, population, authors and numbers of samples examined, the frequencies of each of the groups, the calculated gene-frequency and, in the last column, the figure $\mathrm{D} / \sigma$. The vast bulk of the material has been published in the form of the groups $\mathrm{O}, \mathrm{A}, \mathrm{B}$, and $\mathrm{AB}$, but there are sections where the sub-groups of $A$ have been wholly, or partially, classified. The authors say that "the classification adopted for the data is primarily topographical" ; both place and population are well covered, and the population column includes racial or tribal names where appropriate.

In the largest section of the work, the gene-frequencies have been calculated according to Bernstein's formula, but in the section where the subgroups of $\mathbf{A}$ are completely classified the maximum likelihood method is used. The figure $D / \sigma$ in the last column is given in preference to the usual $\chi^{2}$; it is a measure of the deficiency or excess of the group $A B$ in the results as compared with the calculated frequency. The authors consider that this value allows the reader to make his own estimate of the reliability of the results with respect to genetical homogeneity or accuracy of testing. It is unfortunate that the authors did not write a more comprehensive introduction, giving details of the statistical calculations and more details of the factors which affect the value of $D / \sigma$, with a discourse upon the interpretation of the results ; for the average reader this would have been most helpful. The claim of the authors that this single figure gives a general indication of the reliability of the results is probably valid, but others might well have need to consult the original paper to obtain an accurate estimate of a particular work.

The book is an excellent reference book, with good typography. It is easy to read and the tables are set out (and the book opened) in the long way, which makes them easy to see; but the book is not so easy to fit into a bookcase. To have all this information available in such a small compass is, indeed, valuable for all who are concerned with blood groups, whether they are hæmatologists, anthropologists or geneticists. Dr. Mourant and his colleagues are to be congratulated on the production of this extremely comprehensive and unique work.

F. Stratton

\section{FACTORS AND CAUSES OF INFECTIVE DISEASES}

The Aetiology of Infective Diseases

With Special Reference to the Subsidiary and Important Non-specific Factors. By Prof. Reginald Lovell. Pp. viii +136. (London: Angus and Robertson, Ltd., 1958.) 27s. $6 d$.

$\mathbf{N}$ this book Prof. Lovell, whose experience and authority are well known, gives us the substance of lectures which he delivered in the Department of Microbiology and Public Health at Michigan State University in 1955. He intends the book to stimulate University in interest in the philosophy of epidemiology; both of the aims are certainly achieved. Much knowledge of fact is also added in the author's clear and persuasive style. Though the text refers largely to diseases of domesticated and other animals, the relationship between these and the diseases of man is well brought out. 